\title{
Molluscan
}

Molluscan Research

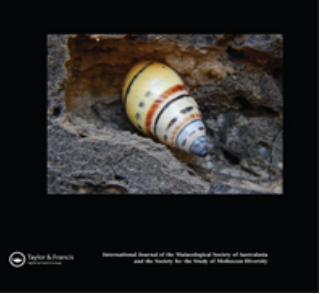

\section{Redescription of Acmella tersa (Benson, 1853), the type species of Acmella W.T. Blanford, 1869 (Gastropoda: Assimineidae), from Meghalaya, Northeast India}

Nipu Kumar Das, Barna Páll-Gergely, Fred Naggs, Richard C. Preece, Tom S. White \& Neelavar Ananthram Aravind

To cite this article: Nipu Kumar Das, Barna Páll-Gergely, Fred Naggs, Richard C. Preece, Tom S. White \& Neelavar Ananthram Aravind (2021) Redescription of Acmella tersa (Benson, 1853), the type species of Acmella W.T. Blanford, 1869 (Gastropoda: Assimineidae), from Meghalaya, Northeast India, Molluscan Research, 41:4, 324-331, DOI: 10.1080/13235818.2021.1991255

To link to this article: https://doi.org/10.1080/13235818.2021.1991255

\section{曲 Published online: 14 Nov 2021.}

\section{Submit your article to this journal $\longleftarrow$}

Џ Article views: 23

Q View related articles $₫$

View Crossmark data $\asymp$ 


\title{
Redescription of Acmella tersa (Benson, 1853), the type species of Acmella W.T. Blanford, 1869 (Gastropoda: Assimineidae), from Meghalaya, Northeast India
}

\author{
Nipu Kumar Das (D) ${ }^{a, b}$, Barna Páll-Gergely (D) ${ }^{c}$, Fred Naggs ${ }^{d}$, Richard C. Preece ${ }^{e}$, Tom S. White (D) ${ }^{d}$ and \\ Neelavar Ananthram Aravind (iD) ${ }^{a, f}$ \\ a Suri Sehgal Center for Biodiversity and Conservation, Ashoka Trust for Research in Ecology and the Environment (ATREE), Bangalore,

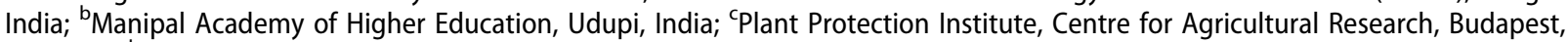 \\ Hungary; ${ }^{d}$ Department of Life Sciences, Natural History Museum, London, SW7 5BD, UK; ${ }^{\text {e} D e p a r t m e n t ~ o f ~ Z o o l o g y, ~ U n i v e r s i t y ~ o f ~}$ \\ Cambridge, Cambridge, UK; fYenepoya Research Center, Mangalore, India
}

\begin{abstract}
The type species of the assimineid genus Acmella W.T. Blanford, 1869 is Cyclostoma tersum Benson, 1853, originally described from 'Musmai' [Mawsmai], Meghalaya, Northeast India. No specimens from Benson's type series can be traced, and contemporary shells collected from the type locality in museum collections are extremely worn. It has therefore been impossible to examine shell microsculpture, an important taxonomic character in the diagnosis of species of Assimineidae, using museum specimens. In order to provide better diagnostic characters for the genus Acmella, we redescribe and illustrate Acmella tersa from newly collected specimens, one of which is designated as the neotype. We also provide a list of all known species attributed to Acmella.
\end{abstract}

\section{ARTICLE HISTORY}

Received 12 May 2021

Final version received 4

October 2021

\section{KEYWORDS}

Musmai; neotype; taxonomy; systematics

\section{Introduction}

The genus Acmella W.T. Blanford, 1869 (Caenogastropoda: Truncatelloidea: Assimineidae), has been reported from a large geographical area, ranging from northeastern India through the Andaman Islands and Borneo to the Philippines and Japan (Blanford 1869; Benthem Jutting 1963; Zilch 1967; Fukuda and Mitoki 1995; Vermeulen and Junau 2007; Vermeulen et al. 2015; Foon et al. 2017; Auffenberg and PállGergely 2020; Páll-Gergely 2020). However, it has not been possible to compare putative Acmella species with the type species of the genus, Cyclostoma tersum Benson, 1853. Despite extensive searches in the University Museum of Zoology, Cambridge (UMZC), which holds the majority of Benson's type material, and the Natural History Museum (NHM), London, the type series cannot be located (Preece et al. in press). A specimen in the ZSI (NZSI M.30156/ 7), labelled as a 'type', has no connection to Benson and cannot be considered part of the type series (Preece et al. in press). Contemporary reviews of the genus (e.g. Blanford 1869) were similarly unable to examine Benson's type material, suggesting that it had been lost at an early stage. Blanford instead described fresh shells provided by H.H. GodwinAusten, which he identified as Acicula (Acmella) tersa. The identity of Acmella tersa, and the status of Acmella, have therefore been uncertain for over 150 years. Recent investigations in the vicinity of the type locality resulted in the rediscovery of the species, which is here redescribed, providing a stronger basis for the recognition of Acmella tersa as a valid species and Acmella as a genus.

\section{Materials and methods}

\section{Collection site}

Specimens were collected from Mawsmai Cave $\left(25.245^{\circ} \mathrm{N}, 91.72405^{\circ} \mathrm{E}\right)$, located approximately $6 \mathrm{~km}$ south of Cherrapunjee in the East Khasi Hills District of Meghalaya State, Northeast India (Figure 1). Meghalaya shares an international border with Bangladesh to the south and has Assam to the west and north. The cave is part of an extensive network of around 1580 natural limestone caves in the Meghalaya region. Some of these have also yielded assemblages of fossil molluscs dating back to the Miocene (Lyngdoh et al. 1999). A band of limestone interstratified with beds of sandstone extends along the southern and eastern border of the Meghalaya plateau (Harries et al. 2008). The limestone is not continuous, due to differential tectonic uplift, associated faults and deeply incised river valleys. The southern edge of Meghalaya is characterised by an extensive band of limestone extending approximately $200 \mathrm{~km}$ from east to west and $30 \mathrm{~km}$ wide (Harries et al. 2008). The vegetation immediately surrounding the cave is evergreen forest. The climate is subtropical and mild, with dry 


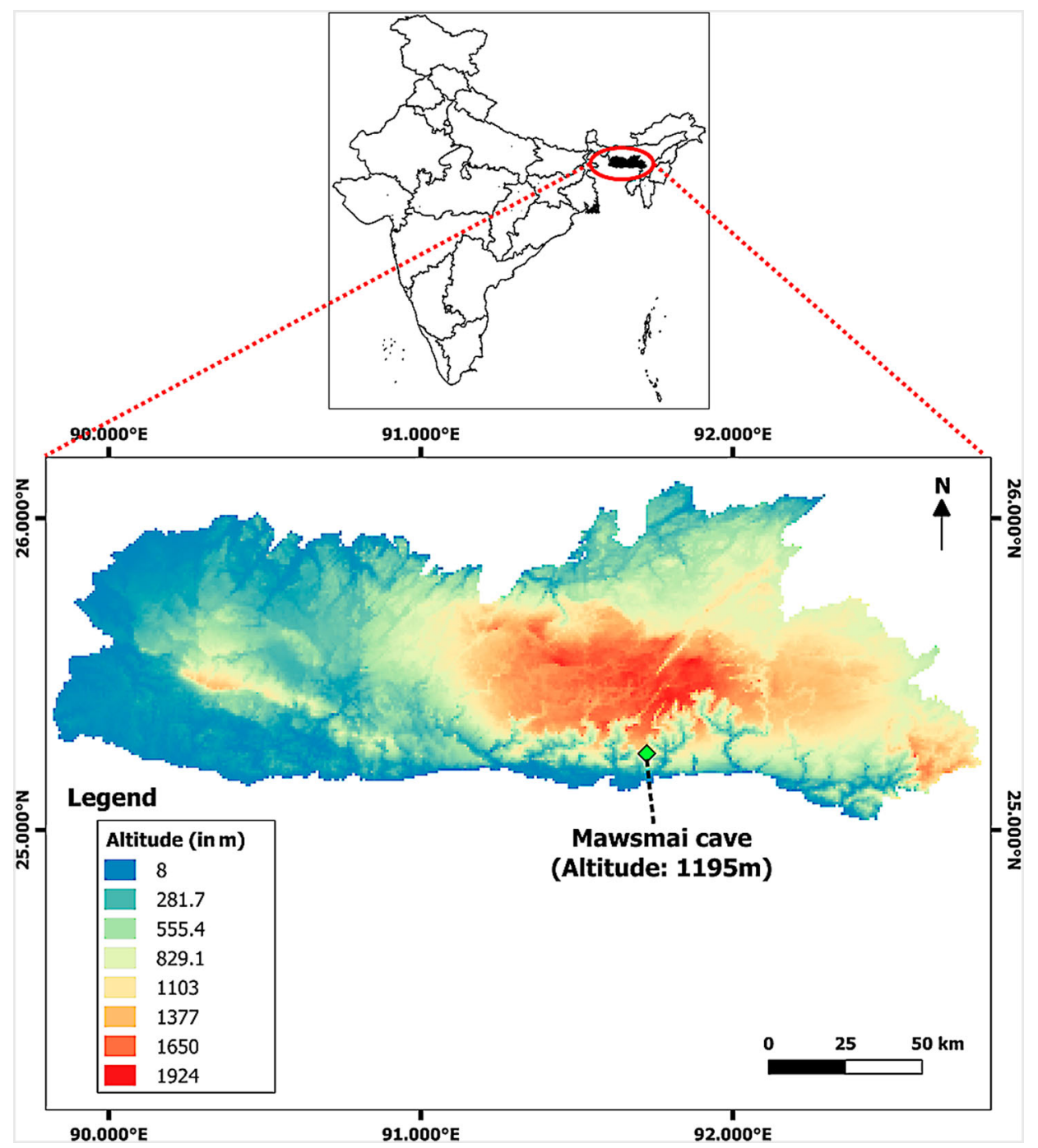

Figure 1. Map showing the location of Mawsmai cave in Meghalaya, northeastern India.

conditions prevailing outside of the May to October monsoon season, when torrential rains give rise to the highest recorded rainfall in the world $(>11,000 \mathrm{~mm}$ per year). The coldest month is January.

The snails were collected from the walls of the cave by hand and were stored in vials for later identification. In the laboratory, the specimens were washed carefully with water to remove sediment from the shell and examined under a Nikon Stereo-microscope (SMZ1270). The images were taken using a Keyence Digital microscope (VHX-6000 series). The various shell measurements (Figure 2) were acquired using ImageJ (version 1.8.0_112).

\section{Abbreviations}

Institutional. ATREE: Ashoka Trust for Research in Ecology and the Environment (Bengaluru, India); NHM: the Natural History Museum (London, UK); NHMUK: when citing registered material deposited in the NHM; UMZC: University Museum of Zoology (Cambridge, UK), ZSI/WGRC: Zoological Survey of India,
Western Ghat Regional Centre (Kerala, India); NZSI: when citing registered material deposited in the ZSI.

Measurements. $\mathrm{AA}=$ Angle of aperture, $\mathrm{AH}=$ Aperture height, $\mathrm{ApA}=$ Aperture area, $\mathrm{APWH}=$ Antepenultimate whorl height, APWD $=$ Antepenultimate whorl diameter without aperture, APWDA $=$ Antepenultimate whorl diameter with aperture, $A W=$ Aperture width, $\mathrm{LWH}=$ Last whorl height PrW $=$ Protoconch width, $\mathrm{PWH}$ $=$ Penultimate whorl height, $\mathrm{PWD}=$ Penultimate whorl diameter without aperture, PWDA $=$ Penultimate whorl diameter with aperture, $\mathrm{RI}=$ Ribs inclination, $\mathrm{SH}=$ Shell height, $\mathrm{SI}=$ Suture Inclination, $\mathrm{SpH}=$ Spire height, SpW $=$ Spire width, SW $=$ Shell width, WSABW $=$ Width of the suture above the body whorl, WSAPW = Width of the suture above the penultimate whorl, WSAAW = Width of the suture above the antepenultimate whorl.

\section{Systematics}

Family Assimineidae Adams \& Adams, 1856 Subfamily Ekadantinae W.T. Blanford, 1869 Genus Acmella W.T. Blanford, 1869 


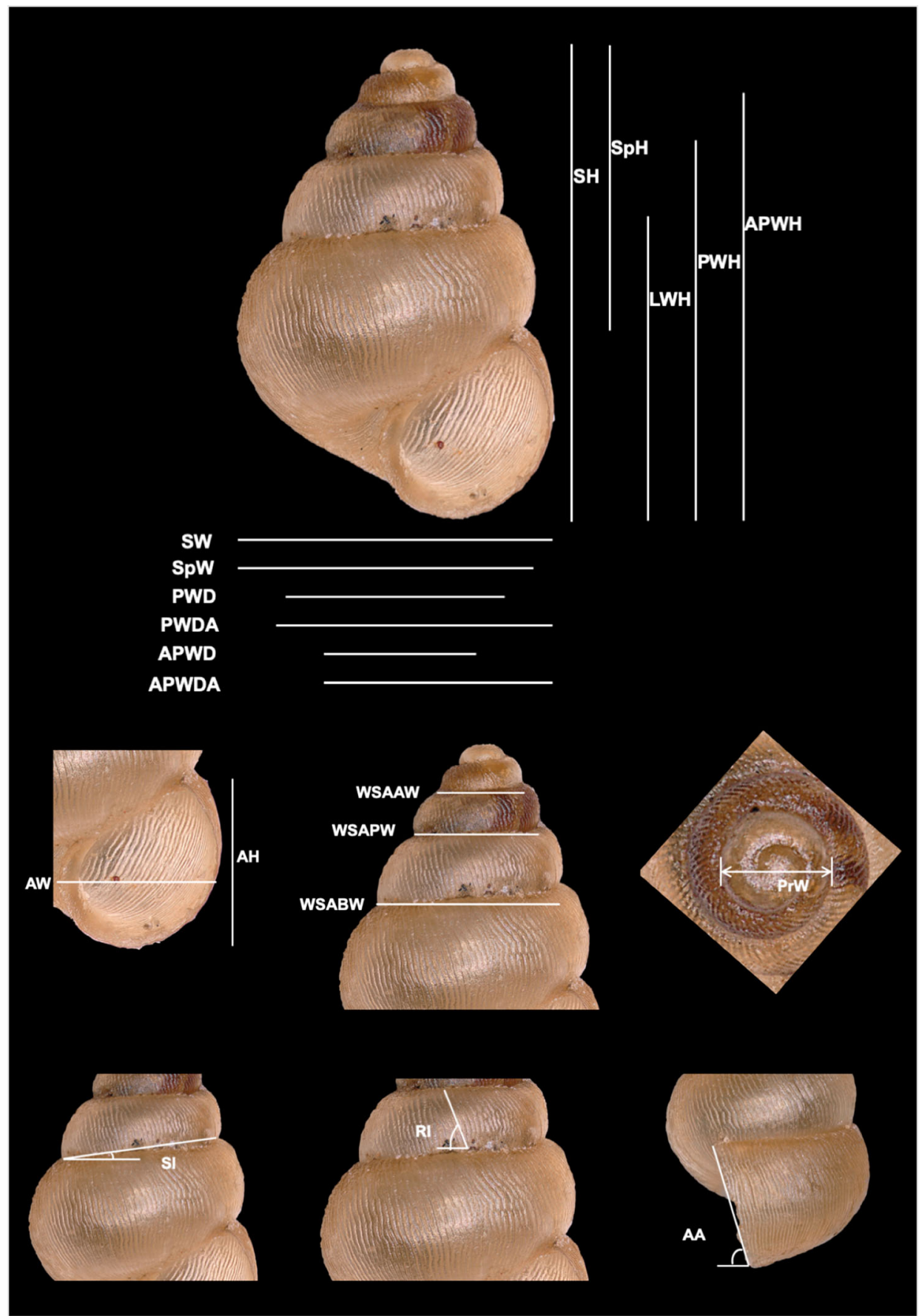

Figure 2. Shell measurements used in the description of the species.

Acicula (Acmella) W.T. Blanford, 1869: 178

Acmella.-W.T. Blanford, 1870: 370; Nevill 1878: 251; Vermeulen et al. 2015: 6.

Type species Cyclostoma tersum Benson, 1853 by monotypy

\section{Remarks}

A proper diagnosis of the genus can be only written following a full generic revision. Based on published literature, a review of the species hitherto included in Acmella shows that they are all minute and ovoidconical in shape, but are very diverse in terms of shell sculpture, and inhabit an enormously wide area from the Himalaya to the Philippines and Japan. This suggests that Acmella species as currently understood might belong to multiple genera. Due to the small size and morphologically rather simple shell, one of the most obvious differences between species is shell sculpture. Species with radial, converging ribs (e.g. 'Acmella sp.' in Foon et al. 2017, and the group of Acmella with 'radial sculpture predominant' in Vermeulen et al. 2015) appear to be typical; the taxonomic status of all other species is in need of revision.

Acmella tersa (Benson, 1853)

(Figures 2, 3) 


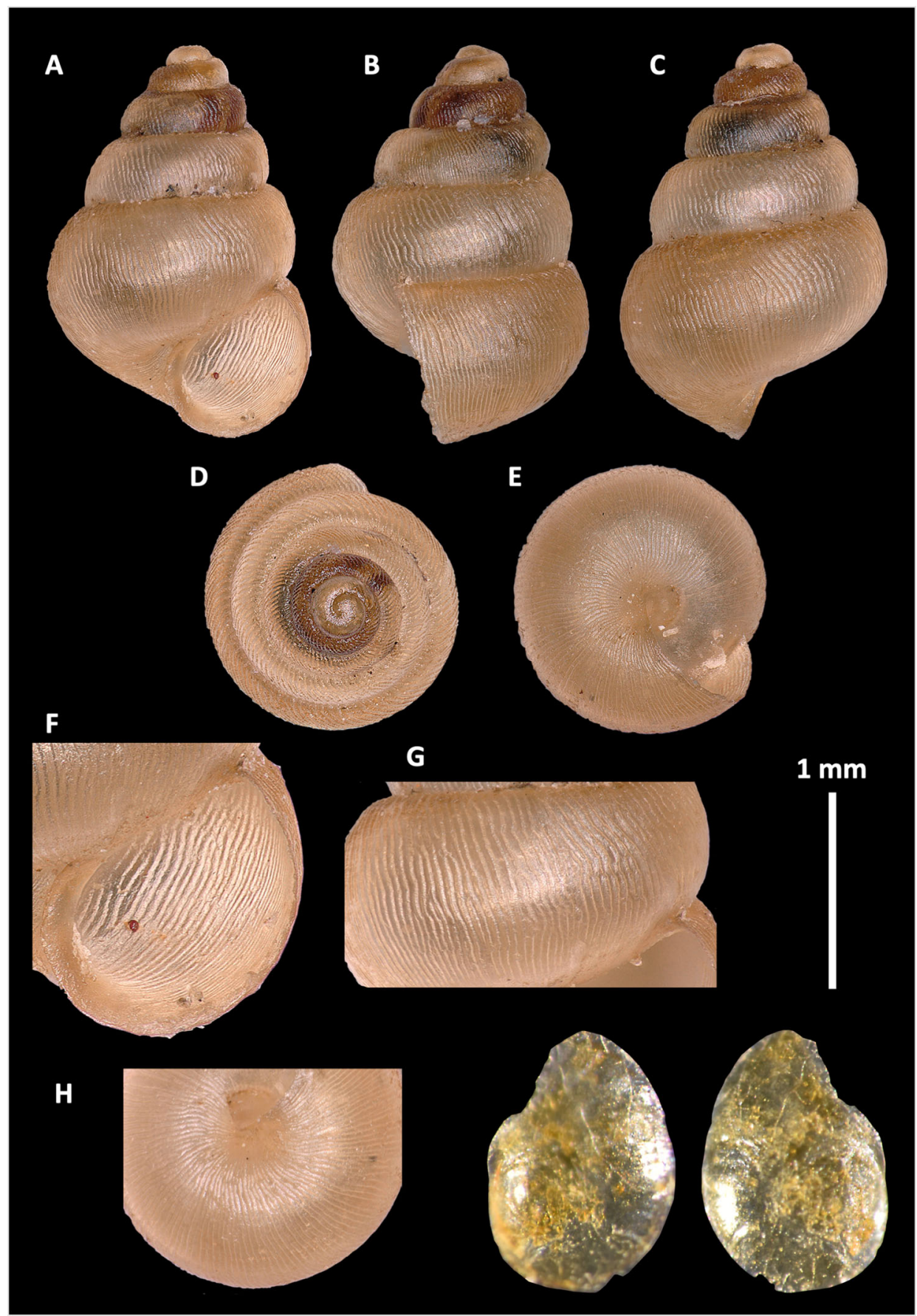

Figure 3. A-H: Neotype of Acmella tersa (Benson, 1853) from Mawsmai cave (ZSI/WGRC/I.RINV. 14959); I-J: operculum of another specimen from the same locality. Scale refers to parts A-E only.

\section{Cyclostoma tersum Benson, 1853: 285}

Cyclostomus? tersus.- Pfeiffer, 1854: 93

Hydrocena tersa.- Benson, 1856: 232; Pfeiffer 1858: 158

Acicula (Acmella) tersa.- Blanford, 1869: 178, pl. 16, fig. 2

Acmella tersa.- Theobald and Stoliczka 1872: 333; Hanley and Theobald 1874 [in 1870-1876]: 48, pl. 117, fig. 1; Nevill 1878: 251; Kobelt and Möllendorff, 1898: 153

Georissa tersa.- Pfeiffer, 1876: 292

Neotype. Mawsmai Cave, Meghalaya, India. $25.245^{\circ} \mathrm{N}$, 91.72405ํㅡ, altitude $1195 \mathrm{~m}$ a.s.l., 4th August, 2018.
Leg. Nipu Kumar Das, N.A. Aravind and Anushree Jadhav (Specimen code A1, ZSI/WGRC/I.R-INV. 14959, Figure 3).

\section{Material examined}

Type material. See above. Other material. Same data as neotype, four additional specimens: (Specimen Code A2: ZSI/WGRC/I.R-INV. 15153, Specimen code A3: ZSI/ WGRC/I.R-INV.15154, Specimen code A4: ATREE/LS/ 001, Specimen code A5: ATREE/LS/002); Khasi Hills, NZSI M.30156/7 (1 shell, labelled as 'type'); NHMUK 1888.12.4.306, single shell from the William Theobald 
collection labelled 'Acmella tersa Benson, Khasi Hills'; NHMUK 1903.vii.i.2455, twenty-three shells from the H.H. Godwin-Austen collection, one of which is glued to a small card, labelled 'Acmella tersa W. Blf., Cherra Poonjee during the rains (G.A.)' with another label 'Acmella tersa W. Blf. 261, Cherra Poongee'. One of these specimens is not Acmella tersa; NHMUK 1891.3.17.936-937, two shells labelled 'Acmella tersa Benson, 70b, Cherra Poonjee, G. Nevill'; NHMUK 20210009, four shells from the H.H. Godwin-Austen collection labelled 'Acicula Acmella tersa Bs'; NHMUK 20210340, six shells from the H.H. Godwin-Austen collection labelled 'Acmella tersa Bs., Cherrapunji, duplicates' and 20210341, three shells from the E.R. Sykes collection labelled 'Acmella tersa Blanf., Cherra'.

\section{Reason for designating a neotype}

ICZN Art. 75.3 (ICZN 1999) lists several qualifying conditions that must be met when designating a neotype. Here we include statements to fulfil these requirements.

In the absence of type specimens of Acmella tersa, there is an exceptional need to designate a neotype in order to fix the taxonomic status of the nominal taxon. Several Acmella species have been described from an extremely wide geographic area (India to Japan) in the last one and a half centuries without reference to the type species of the genus. Differences amongst these species, primarily in the shell sculpture, could result in the recognition of several distinct genera within the current concept of Acmella. However, this would only be possible once the taxonomic status of the type species has been clarified. For this reason, we propose the designation of a neotype for A. tersa. The newly collected Acmella tersa specimens, including the neotype, match the original description of Cyclostoma tersum in all aspects (size, shell and aperture shape, number of whorls, sculpture), and were collected at the type locality.

\section{Redescription}

Shell minute, shape typical assimineid (conical to ovoid); whorls 4.5-5; colour brownish corneous, shell somewhat semi-transparent; protoconch finely granulose, teleoconch with irregular, rather strong, somewhat wavy ribs, some of which may converge; aperture prosocline, only slightly oblique to shell axis from lateral view, elongate ovoid with pointed parieto-palatal angle; peristome sharp, not expanded; umbilicus narrow, nearly closed.

Operculum. Blanford (1869: 178) examined specimens provided by Godwin-Austen (who also sent him diagrams of the animal, operculum and radula), describing the operculum as 'horny, extremely thin, and very difficult to isolate; it appears to be paucispiral'. We can confirm the observations of Blanford (1869). Measurements of the operculum are: $\mathrm{H}: 0.667$, W: 0.480. H/W: 1.389 .

Dimensions. (In mm, $n=5$ ). SH 2.14-2.38 (SE 0.05), SW 1.45-1.66 (SE 0.042), SH/SW 1.41-1.57 (SE 0.027), AH 0.83-0.94 (SE 0.024), AW 0.78-0.89 (SE 0.02), AH/ AW 1.05-1.09 (SE 0.007), ApA 0.3-0.38 (SE 0.015), AA 66.59-73.4 (SE 1.208), SpH 1.3-1.52 (SE 0.036), SpW 1.35-1.54 (SE 0.039), LWH 1.38-1.55 (SE 0.033), PWH 1.72-1.9 (SE 0.035), PWD 1-1.18 (SE 0.031), PWDA 1.26-1.46 (SE 0.038), APWH 1.94-2.17 (SE 0.042), APWD 0.68-0.82 (SE 0.024), APWDA 1.07-1.23 (SE 0.03), WSABW 1-1.14 (SE 0.033), WSAPW 0.65-0.77 (SE 0.022), WSAAW 0.42-0.51 (SE 0.014), SI 6.56-9.01 (SE 0.41), RI 65.88-70.92 (SE 1.025), PrW 0.36-0.39 (SE 0.006).

\section{Ecology}

The original specimens were found in 'tree moss at Musmai, near Cherra-poonjee' (Benson 1853: 285). The newly collected specimens came from the surface of moist limestone rocks approximately 4$5 \mathrm{~m}$ inside the entrance of Mawsmai Cave. At this point the cave was almost dark with the exception of a few artificial lights.

\section{Distribution}

This species is known only from the vicinity of the type locality (India: Musmai [=Mawsmai], near Cherrapoonjee [=Cherrapunjee], Khasi Hills, Assam [present-day Meghalaya State]).

\section{Conservation status}

The presence of large numbers of tourists at the only known locality for this minute species of snail potentially poses a significant threat. Furthermore, in order to improve the 'aesthetics' of the cave, paving and cementing have been undertaken near the entrance and artificial lighting has been installed to improve visibility for visitors. Consequently, this species has been assessed as Critically Endangered (CR) B1 and B2 according to IUCN criteria (IUCN 2012).

However, similar investigations of microgastropod faunas in neighbouring caves, and in the general area, have yet to be undertaken and the true distribution of the species is currently unknown. Historical specimens in the NHM suggest that it was relatively common in the nineteenth century, at least in the vicinity of Cherrapunji and Mawsmai, but there has since been extensive limestone quarrying and deforestation in this area, which will undoubtedly have had a 
Table 1. Locality and sculpture of species assigned to Acmella. Those with typical Acmella sculpture are marked with an asterisk.

\begin{tabular}{|c|c|c|c|}
\hline Species & Locality & Sculpture & Source \\
\hline A. bauensis Marzuki, T. S. Liew \& Mohd- Azlan, 2021 & Borneo & very finely reticulated & Marzuki et al. (2021) \\
\hline A. bilamellata (van Benthem Jutting, 1958) & Sumba & glossy & Páll-Gergely (2020) \\
\hline A. caelata Vermeulen \& Junau, 2007 & Borneo & spiral lines & Vermeulen and Junau (2007) \\
\hline A. conica Vermeulen \& Junau, 2007 & Borneo & weak spiral lines & Vermeulen and Junau (2007) \\
\hline $\begin{array}{l}\text { *A. cyrtoglyphe Vermeulen, Liew \& Schilthuizen, } \\
2015\end{array}$ & Borneo & radial, irregular + weak spiral & Vermeulen et al. (2015) \\
\hline A. decolor O. Boettger, 1891 & Banda Islands & $\begin{array}{l}\text { 'matte glossy' with reddish brown spiral } \\
\text { bands }\end{array}$ & Boettger (1891) \\
\hline A. gradata Möllendorff, 1895 & Philippines & glossy & Zilch (1967) \\
\hline A. hyalina Theobald \& Stoliczka, 1872 & Myanmar & 'smooth' & Theobald and Stoliczka (1872) \\
\hline A. isseliana (Tapparone Canefri, 1883) & West Papua & unknown & Tapparone Canefri (1883) \\
\hline A. mellilla Godwin-Austen, 1895 & Andaman Ids & radial lines & Godwin-Austen (1895) \\
\hline A. minima (Habe, 1942) & Japan & smooth & Fukuda and Mitoki (1995) \\
\hline A. minutissima (Maassen, 2000) & Sumatra & stronger spiral + weaker radial & Maassen (2000) \\
\hline A. moreletiana Nevill, 1878 & Nicobar Ids & spiral lines & Nevill (1878) \\
\hline A. nana Vermeulen, Liew \& Schilthuizen, 2015 & Borneo & spiral lines & Vermeulen et al. (2015) \\
\hline A. obtusa Vermeulen \& Junau, 2007 & Borneo & spiral lines & Vermeulen and Junau (2007) \\
\hline A. ovoidea Vermeulen, Liew \& Schilthuizen, 2015 & Borneo & weak spiral lines & Vermeulen et al. (2015) \\
\hline A. parvicostata van Benthem Jutting, 1963 & $\begin{array}{l}\text { West New } \\
\text { Guinea }\end{array}$ & unknown & van Benthem Jutting (1963) \\
\hline A. pirinthella van Benthem Jutting, 1963 & $\begin{array}{l}\text { West New } \\
\text { Guinea }\end{array}$ & unknown & van Benthem Jutting (1963) \\
\hline A. polita Möllendorff, 1887 & Philippines & glossy & Zilch (1967) \\
\hline A. pusilla Quadras \& Möllendorff, 1895 & Philippines & glossy & Zilch (1967) \\
\hline A. regularis (Quadras \& Möllendorff, 1895) & Philippines & finely reticulated & $\begin{array}{l}\text { Auffenberg and Páll-Gergely } \\
\text { (2020) }\end{array}$ \\
\hline A. roepstorffiana Nevill, 1878 & Nicobar Ids & 'regularly, closely, evenly striated' & Nevill (1878) \\
\hline A. striata Vermeulen, Liew \& Schilthuizen, 2015 & Borneo & dense spiral striation + growth lines/ribs & Vermeulen et al. (2015) \\
\hline $\begin{array}{l}\text { A. subcancellata Vermeulen, Liew \& Schilthuizen, } \\
2015\end{array}$ & Borneo & spiral striation + growth lines/ribs & Vermeulen et al. (2015) \\
\hline A. subglabrata (Möllendorff, 1887) & Philippines & finely reticulated & $\begin{array}{l}\text { Auffenberg and Páll-Gergely } \\
\text { (2020) }\end{array}$ \\
\hline A. sutteri van Benthem Jutting, 1958 & Sumba & striated & van Benthem Jutting (1958) \\
\hline${ }^{*} A$. tersa (Benson, 1853) & India, Meghalaya & radial, irregular & this study \\
\hline $\begin{array}{l}\text { A. trachypleura Vermeulen, Luu, Theary \& Anker, } \\
2019\end{array}$ & $\begin{array}{l}\text { Southern } \\
\text { Vietnam }\end{array}$ & radial, irregular & Vermeulen et al. (2019) \\
\hline A. turritella (Möllendorff, 1893) & Philippines & finely reticulated & $\begin{array}{l}\text { Auffenberg and Páll-Gergely } \\
\text { (2020) }\end{array}$ \\
\hline $\begin{array}{l}\text { *A. umbilicata Vermeulen, Liew \& Schilthuizen, } \\
2015\end{array}$ & Borneo & radial, irregular + weak spiral & Vermeulen et al. (2015) \\
\hline A. unilamellata (Benthem Jutting, 1958) & Sumba & Glossy & Páll-Gergely (2020) \\
\hline
\end{tabular}

significant impact. Establishing protected status for this species is therefore important.

\section{Discussion}

The genus Acmella is represented in India by four species: Acmella tersa (Benson, 1853) (type species) from Meghalaya, A. moreletiana Nevill, 1878 and A. roepstorffiana Nevill, 1878, both from the Nicobar Islands (Nevill 1878), and Acmella mellilla GodwinAusten, 1895 from the Andaman Islands. These are listed in Table 1, together with all other Acmella species found in the literature. It is highly probable that more intensive sampling across NE India and in Myanmar will yield species of Acmella additional to those currently known. Cyclostoma milium Benson, 1853 was classified in Acmella by Gude (1921), but examination of Benson's original specimen revealed that it is not a caenogastropod but a pulmonate belonging to the genus Angustopila Jochum, Slapnik \& Páll-Gergely, 2014 (Gastrocoptidae, Hypselostomatinae), thus precluding its retention in Acmella (Preece et al. in press).

Currently, only Acmella cyrtoglyphe Vermeulen et al., 2015 and $A$. umbilicata Vermeulen et al., 2015, both from Borneo (Table 1), are known to possess typical sculpture observed in the type species, A. tersa (converging radial ribs on the last adult whorl). It therefore appears that only these three species belong to Acmella sensu stricto, although in such a supposedly widely distributed group it could also be a convergent character. Further investigation may show that this characteristic sculpture occurs in other Indian species.

Acmella trachypleura Vermeulen et al., 2019 also has a predominantly radial sculpture, but the radial ribs do not converge. Acmella moreletiana and A. roepstorffiana may belong to another genus since they possess sculpture that differs significantly from the type species of Acmella (see Table 1).

Mawsmai Cave is one of the most popular tourist attractions in Meghalaya and therefore increasingly affected by human impacts. Given the highly restricted known distribution of Acmella tersa, this poses a significant threat to the survival of this rare microsnail.

\section{Acknowledgements}

We would like to thank Meghalaya Forest Department for necessary permission to carry out research (Permit no. SBB.19/ABS/Pt.Il/4375), and Ms Anushree Jadhav for help 
during the field work. NAA and NKD are grateful to Dr Priyadarsanan Dharma Rajan for microscope use and Ms Sneha for help during microscopy. We are grateful to Takuma Haga for providing literature. We thank two anonymous reviewers for comments on an earlier version of the manuscript.

\section{Disclosure statement}

No potential conflict of interest was reported by the author(s).

\section{Funding}

Barna Páll-Gergely was supported by the Hungarian Research Fund (OTKA FK 135262), the Bolyai Research Scholarship of the Hungarian Academy of Sciences, the SYNTHESYS Project under Grant GB-TAF-2523, and Department of Biotechnology, Govt. of India for funding (File no. BT/01/17/ NE/TAX).

\section{ORCID}

Nipu Kumar Das (D) http://orcid.org/0000-0002-3436-3104 Barna Páll-Gergely (D) http://orcid.org/0000-0002-6167-7221 Tom S. White (D) https://orcid.org/0000-0001-9056-7286 Neelavera Ananthram Aravind (I) http://orcid.org/0000-00024515-8421

\section{References}

Auffenberg, K. \& Páll-Gergely, B. (2020) Reassignment of three species and one subspecies of Philippine land snails to the genus Acmella Blanford, 1869 (Gastropoda: Assimineidae). Tropical Natural History 20, 223-227.

Benson, W.H. (1853) Additional character of the shell of the cyclostomatous genus Alycæus of Gray, with descriptions of its animal inhabitant, of a fourth species, and of other new Indian Cyclostomata; also, remarks on an unrecorded character in Diplommatina. The Annals and Magazine of Natural History Ser 2(9), 283-287.

van Benthem Jutting, W.S.S. (1958) Landmollusken von Sumba. Verhandlungen der naturforschenden Gesellschaft Basel 69, 90-117.

van Benthem Jutting, W.S.S. (1963) Non-marine Mollusca of west New Guinea. Part 1. Mollusca from fresh and brackish waters. Nova Guinea, Zoology 20, 409-521.

Blanford, W.T. (1869) On the animal and operculum of Georissa, W. Blanf., and on its relations to Hydrocena, Parreys; with a note on Hydrocena tersa, Bens., and H. milium, Bens. The Annals and Magazine of Natural History Ser 4(3), 173-179.

Blanford, W.T. (1870) On Georissa, Acmella (Cyclostoma tersum, Bens.), Tricula, and Cyathopoma millium [sic], Bens. The Annals and Magazine of Natural History Ser 4 (6), 368-370.

Boettger, O. (1891) Ad. Strubelĺs Konchylien aus Java II und von den Molukken. Bericht über die Senckenbergische Naturforschende Gesellschaft in Frankfurt am Main 1891, 241-318, pls 3-4.

Foon, J.K., Clements, G.R. \& Liew, T.S. (2017) Diversity and biogeography of land snails (Mollusca, Gastropoda) in the limestone hills of Perak, Peninsular Malaysia. ZooKeys 682, 1-94.

Fukuda, H. \& Mitoki, T. (1995) A revision of the family Assimineidae (Mollusca: Gastropoda: Neotaenioglossa) stored in the Yamaguchi Museum. Part 1: subfamily Omphalotropidinae. Bulletin of the Yamaguchi Museum 21, 1-20.

Godwin-Austen, H.H. (1895) List and distribution of the LandMollusca of the Andaman and Nicobar Islands, with descriptions of some supposed new species. Proceedings of the Zoological Society of London 1895, 438-457.

Gude, G.K. (1921) The Fauna of British India including Ceylon and Burma: Mollusca III. Land Operculates (Cyclophoridae, Truncatellidae, Assimineidae, Helicinidae). Taylor and Francis, London.

Hanley, S.C. \& Theobald, W. (1870-1876) Conchologia Indica, being Illustrations of the Land and Freshwater Shells of British India. L. Reeve \& Co., London.

Harries, D.B., Ware, F.J., Fischer, C.W., Biswas, J. \& KharpranDaly, B.D. (2008) A review of the biospeleology of Meghalaya, India. Journal of Cave and Karst Studies 70, 163-176.

ICZN (1999) International Code of Zoological Nomenclature, 4th edition. International Trust for Zoological Nomenclature, London.

IUCN (2012) IUCN Red List Categories and Criteria: Version 3.1, 2nd edition. IUCN, Gland and Cambridge, UK.

Kobelt, W. \& von Möllendorff, O. (1898) Catalog der gegenvärtig lebend bekannten Pneumonopomen. Nachrichtsblatt der Deutschen Malakozoologischen Gesellschaft 30, 129-160.

Lyngdoh, B.C., Tiwari, R.P. \& Kachhara, R.P. (1999) Miocene molluscan biostratigraphy of the Garo Hills, Meghalaya, India. Journal of the Palaeontological Society of India 44, 55-67.

Maassen, W.J.M. (2000) Notes on terrestrial molluscs of Sumatra, Indonesia, with descriptions of ten new species (Gastropoda, Prosobranchia \& Pulmonata). Basteria 64, 137-150.

Marzuki, M.E.b., Liew, T.S. \& Mohd-Azlan, J. (2021) Land snails and slugs of Bau limestone hills, Sarawak (Malaysia, Borneo), with the descriptions of 13 new species. ZooKeys 1035, 1-113.

Nevill, G. (1878) Hand List of Mollusca in the Indian Museum, Calcutta. Part l. Gastropoda. Pulmonata and Prosobranchia-Neurobranchia. Office of the Superintendent of Government Printing, Calcutta.

Páll-Gergely, B. (2020) A new genus of Diplommatinidae from the Andaman Islands (Gastropoda: Caenogastropoda: Cyclophoroidea). Molluscan Research 40, 247-250.

Pfeiffer, L. (1854) Nachträge zur Monographie Pneumonopomorum. Malakozoologische Blätter 1, 80-111.

Pfeiffer, L. (1858) Monographia Pneumonopomorum viventium. Supplementum primum. Theodori Fischeri, Cassellis; Williams \& Norgate, London; Friedr. Klincksieck, Paris.

Pfeiffer, L. (1876) Monographia Pneumonopomorum viventium, accedente fossilium enumeratione. Supplementum tertium, monographiae Auriculaceorum parte secunda auctum. Th. Fischer, Cassel.

Preece, R.C., White, T.S., Raheem, D.C., Ketchum, H., Ablett, J.D., Taylor, H., Webb, K. \& Naggs, F. William Benson and the origin of the golden age of malacology in British India. Biography, illustrated catalogue and evaluation of his molluscan types. Tropical Natural History (in press).

Tapparone Canefri, C. (1883) Fauna malacologica della Nuova Guinea e delle isole adiacenti. Parte I, Molluschi estramarini. Annali del Museo Civico di storia naturale di Genova 19, 1-313.

Theobald, W. \& Stoliczka, F. (1872) Notes on Barmese and Arakanese land shells, with descriptions of a few species. Journal of the Asiatic Society of Bengal 41(2), 329-334. pl. 11. 
Vermeulen, J.J. \& Junau, D. (2007) Bukit Sarang (Sarawak, Malaysia), an isolated limestone hill with an extraordinary snail fauna. Basteria 71, 209-220.

Vermeulen, J.J., Liew, T.S. \& Schilthuizen, M. (2015) Additions to the knowledge of the land snails of Sabah (Malaysia, Borneo), including 48 new species. ZooKeys $531,1-139$
Vermeulen, J.J., Luu, H.T., Theary, K. \& Anker, K. (2019) Newspecies of land snails (Mollusca: Gastropoda: Caenogastropoda and Pulmonata) of the Mekong Delta Limestone Hills (Cambodia. Vietnam). Folia Malacologica 27, 7-41.

Zilch, A. (1967) Die Typen und Typoide des Natur-Museums Senckenberg, 36: Mollusca, Assimineidae. Archiv für Molluskenkunde 96, 67-100. pls. 1-6. 